\title{
Lymphocytes and thyroid cancer: more to it than meets the eye?
}

\section{Frank Weber}

Department of General-, Visceral- and Transplantations Surgery, Division of Endocrine Surgery, Medical Faculty, University Hospital Essen, University of Duisburg-Essen, Hufelandstrasse 55, 45130 Essen, Germany
Correspondence should be addressed to $F$ Weber

Email

frank.weber@uk-essen.de

\begin{abstract}
Immune responses by innate and adaptive immune cells are crucial for the suppression of carcinogenesis and tumor spread. Effector $\mathrm{T}$ cells such as, cytotoxic $\mathrm{CD} 8^{+} \mathrm{T}(\mathrm{CTL})$, natural killer (NK), and NK T cells (NKT cells) prevent tumor growth by their ability to induce apoptosis in cancer cells. To circumvent anti-tumor immunity, tumors commonly attract regulatory T cells (Treg), which suppress the function of CTL and NKT cells in a contact- and cytokine-dependent manner. Recent findings in patients with thyroid cancer have suggested that an imbalance between immune suppressive and anti-tumor cells occurs during thyroid carcinogenesis. However, the composition and regulation of immune responses in thyroid cancer are still elusive and a comprehensive immune profile of thyroid cancer is missing. In this issue of Endocrine-Related Cancer, Imam et al. compare immune profiles between patients with papillary thyroid carcinoma and autoimmune thyroiditis. Their data suggest that an imbalance between immunosuppressive Treg cells and effector T cells occurs during papillary thyroid carcinogenesis. Their study identified double-negative T cells as a novel key factor involved in this process. Future research is required to recapitulate these findings, to elucidate the mechanisms by which the immune response is regulated and to evaluate if this process might be used for the therapeutical management of thyroid cancer.
\end{abstract}
Key Words
- thyroid carcinoma
- tumor immunology
- Treg
- $\mathrm{CD}^{-}{ }^{-} \mathrm{CD} 8^{-} \mathrm{T}$ cells

\section{Thyroiditis and thyroid cancer}

In the beginning of the 19th century, the Japanese surgeon, Hakaru Hashimoto, first described a thyroid pathology dominated by fibrosis and diffuse lymphocyte infiltration. Hashimoto's thyroiditis (HT) is the most common autoimmune thyroid disorder. Hallmark of HT is the progressive loss of thyroid epithelial cells that are replaced by an infiltration of mononuclear cells (T cells) that eventually leads to thyroid atrophy and hypothyroidism (Caturegli et al. 2013, Jankovic et al. 2013).

The relationship between thyroiditis, especially HT, and differentiated thyroid cancer (especially papillary thyroid cancer (PTC)) has a long history of debate. The current literature on this topic is inconsistent and there are conflicting data on the association between PTC and HT. While some studies suggest that these two thyroid conditions are positively correlated, others failed to find an association (Segal et al. 1985, Ott et al. 1987, Eisenberg \& Hensley 1989, Di Pasquale et al. 2001, Mechler et al. 2001, Pisanu et al. 2003). However, it is important to note that the caveat is most pronounced between studies using paraffin-embedded tissue (i.e. thyroidectomy specimens) and those using fine-needle aspiration (FNA) biopsy samples. On the basis of FNA studies including over 18000 patients, the prevalence of PTC in HT is estimated to about $1.2 \%$ with a non-significant risk ratio (RR) of 0.69 . In contrast, prevalence of PTC in HT based on about 10000 archival thyroid specimens is $27 \%$ (RR 1.59;

Published by Bioscientifica Ltd. 
Ott et al. 1987, Kashima et al. 1998, Loh et al. 1999, Kebebew et al. 2001, Jankovic et al. 2013). Thus, limiting the analysis to archival thyroidectomy specimens might carry a selection bias because the indication for surgery is commonly due to the presence of suspicious nodules. On the other hand, there is a consensus that peritumeral chronic lymphocytic infiltration alters the clinical presentation of differentiated thyroid cancer. Kebebew and others found that chronic lymphocytes infiltration in patients with PTC correlates with an improved outcome or less aggressive disease (Eisenberg \& Hensley 1989, Kashima et al. 1998, Kebebew et al. 2001).

At first notion, this does not match up as on the one hand lymphocyte infiltration might contribute to PTC carcinogenesis (i.e. pro carcinogenic) but on the other hand the presence of these inflammatory cells exert protective effects and is associated with a less aggressive disease (i.e. anti carcinogenic). Explanation is found in the diversity of these mononuclear cell that each not only present with unique cellular features - not seen on standard H\&E microscopy - but also distinct functional properties ranging from pro-oncogenic and immunosuppressive to the ability to induce an effective host antitumor response (Guarino et al. 2010, Gogali et al. 2012).

\section{Tumor infiltrating lymphocytes and cancer progression}

The field of immunology expands at rapid pace and has been become much more complex than was initially thought when the difference between B- and T-lymphocytes was discovered in the late 1960s (Peterson 2012, Hillhouse \& Lesage 2013). Today, there is no aspect in medicine that is not influenced or even controlled by the immune system.

Tissues are constantly challenged by a multitude of exogenous and endogenous stressors endangering their structural and genomic integrity. It is evident that the human immune system is not only responsible to protect the organism from the harmful outside intruders but also from the enemies within. For the latter, a comprehensive system identifies and eliminates mutated and dedifferentiated cells, using the innate and adaptive immune system (Coussens \& Werb 2002, Peterson 2012). Homing of lymphocytes into the tumor stroma creates an environment, in which the immune system homeostasis and control of self-tolerance are strongly modified (Balkwill \& Mantovani 2001, Coussens \& Werb 2002). Cytotoxic CD8 ${ }^{+} \mathrm{T}$ cells (CTL), natural killer (NK), and NK $\mathrm{T}$ cells (NKT cells) are important suppressors of tumor growth because of their cytotoxic function and ability to destroy cancer cells (Grivennikov \& Karin 2010). Other populations such as the interleukin 10 (IL10)-producing $\mathrm{CD}^{+}{ }^{+}$T-helper 1 (Th1) cells, the TGF-b-producing CD4 ${ }^{+}$ $\mathrm{Th} 3$ cells, $\mathrm{CD}^{+}{ }^{+} \mathrm{CD}_{2} 5^{+}$FoxP3 $^{+} \mathrm{T}$ cells (regulatory $\mathrm{T}$ (Tregs)), $\mathrm{CD}^{-}$and $\mathrm{CD}^{-}$(double negative (DN)) T cells share the ability to inhibit immune response, induce tolerance, and help the neoplastic cells to escape the immune attack (Strober et al. 1996, Dittel 2008, Shevach 2009, Juvet \& Zhang 2012, Peterson 2012, Hillhouse \& Lesage 2013, Muranski \& Restifo 2013). Interestingly, this fundamental concept that there is a strong link between chronic inflammation and cancer dates back to the 18th century when Virchow proposed that cancer initiates at sites of chronic inflammation (Balkwill \& Mantovani 2001).

Over the last years, the various cell types that make up this immunoreactive tumor stroma have been delineated. These cells are characterized by their cell surface markers and the cytokines that they produce. Extensive research allowed to define how distinct $\mathrm{T}$ cell populations contribute to cancer progression. The most common ones express CD4 (T-helper cells) and CD8 (cytotoxic lymphocytes) (Peterson 2012).

$\mathrm{CD}^{+}{ }^{+} \mathrm{T}$-cells hold a key role in the modulation of immune response. These naïve $\mathrm{CD} 4^{+}$cells are capable to expand into functionally distinct subpopulations that express a unique set of cytokines. They are thought to differentiate into divers forms with unique functional properties such as Th1, Th2, Th17, and Tregs. Tregs (CD4 ${ }^{+}$, IL2 receptor $\alpha$-chain $\left(\mathrm{CD} 25^{+}\right)$, and Forkhead box P3 $\left(\mathrm{FoxP}^{+}\right)$) as a subset of T-lymphocytes, constituting $5-10 \%$ of $\mathrm{CD}^{+}{ }^{+} \mathrm{T}$ cells, are defined by the presence of the FoxP3 transcription factor that is critical for their functional capacity (Shevach 2009, Sakaguchi et al. 2010). They mediate a multiplicity of actions, such as the inhibition of T cell-mediated autoimmune and anti-tumor response (Nishikawa \& Sakaguchi 2010, Sakaguchi et al. 2010). Furthermore, they are able to induce tolerance by repressing $\mathrm{CD}^{+}{ }^{+}, \mathrm{CD}^{+}{ }^{+}$cells as well as NK-cells, dendritic cells, mast cells, and monocytes/macrophages (Coutinho et al. 2005, Bluestone et al. 2008, Dittel 2008, Simpson et al. 2008, Akdis \& Akdis 2009). Thus, Tregs play an important role in evasion of anti-tumor $\mathrm{T}$ cell response in cancer cells.

In addition, there are $\mathrm{CD} 4$ negative and $\mathrm{CD} 8$ negative $\left(\mathrm{CD}^{-}\right.$and $\left.\mathrm{CD}^{-}\right)$, thus DN Tregs that promote the development of tolerance (Strober et al. 1996). This cell population has been identified in xenotransplant models (Chen et al. 2003, Ma et al. 2008). On the basis of animal studies, it has been shown that DN cells show only limited suppressive function in naïve mice, while DN Tregs are

Published by Bioscientifica Lto. 
strongly suppressive in xenograft recipients and induce tolerance to such extent that organ rejection is prevented (Strober et al. 1996, Chen et al. 2003, Ma et al. 2008, Juvet \& Zhang 2012). Similarly, tumors develop strategies to escape cytotoxic T cells and are able to induce a micromilieu that inhibits the anti-neoplastic function of effector $\mathrm{T}$ cells and memory $\mathrm{CD} 8^{+} \mathrm{T}$ cells.

\section{Tumor infiltrating lymphocytes in thyroid cancer}

In this issue of Endocrine-Related Cancer, Imam et al. (2014) present in their study 'Lymphocytic profiling in thyroid cancer provides clues for failure of tumor immunity' a phenotypic analysis of thyroid tumor-associated lymphocytes and compare those with lymphocytes found in autoimmune thyroiditis. They show an infiltration of tumors with $\mathrm{CD}^{+}$and $\mathrm{CD}^{+}{ }^{+} \mathrm{T}$ cells as well as $\mathrm{CD} 3^{+}$but $\mathrm{CD} 4^{-}$and $\mathrm{CD} 8^{-}$DN cells. Patients with PTC harbored a higher frequency of $\mathrm{CD}^{+}{ }^{+} \mathrm{FOXP}^{+} \mathrm{T}$ cells when compared to patients with HT. Furthermore, the authors identified $\mathrm{CD}^{-}$and $\mathrm{CD} 8^{-} \mathrm{DN} \mathrm{T}$ cells as a dominant cell type associated with thyroid cancer and showed that these cells produce IFN $\lambda$ and IL17 when stimulated ex vivo. The authors claim that DN T cells downregulate proliferation and cytokine production of activated effector $\mathrm{T}$ cells and suggest that these $\mathrm{DN} T$ cells are responsible for the suppression of tumor immunity. The identification of DN $\mathrm{T}$ cells is a novel observation and if it holds true, it would not only add to the growing understanding on the role of tumor infiltrating lymphocytes in thyroid cancer but might open a new approach for thyroid cancer therapy.

However, previous studies have analyzed the $\mathrm{T}$ cell populations in thyroid cancer as well, but have failed to find a predominant DN T cell population. In a recent study by French et al. the group has identified $\mathrm{CD} 4^{+}$ $\mathrm{T}$ lymphocytes as the predominant tumor-associated $\mathrm{T}$ cell population in PTC. An increase in $\mathrm{CD} 4^{+}$cells was found in larger tumors. The infiltration of PTC stroma with Tregs correlated with disease stage and metastasis. Interestingly, while Tregs were found in all tumor samples, their frequency was highly variable ranging from 12 to $36 \%$ of all CD ${ }^{+}$T cells (French et al. 2010). Similarly, Gogali et al. examined the thyroid gland of 65 patients with PTC, 25 patients with thyroid nodular goiter (TNG), and 50 healthy controls for the presence of lymphocyte infiltration (Treg and NK cells). The authors found that there was a significant increase in Treg infiltration in thyroid tissue of PTC patients compared with TNG samples. Interestingly, the difference was more pronounced based on flow cytometry than compared with immunohistochemistry (IHC), indicating that limitations and potential lack of comparability between these techniques. Furthermore, Gogali et al. (2012) found a significant increase in the NK cell fraction (5.6 vs $2.7 \%$ ), while $\mathrm{CD} 4(+)$ (38 vs $32 \%$ ) and $\mathrm{CD} 8(+)$ (36 vs $30 \%$ ) cell fractions remained unchanged. In their study, increased Treg infiltration was positively correlated with advanced disease stage, while NK infiltration was negatively correlated.

Imam et al. in his study reported an almost complete absence of Foxp $3^{+} \mathrm{CD}_{2} 5^{+} \mathrm{CD}^{+}{ }^{+} \mathrm{CD}^{+}{ }^{+} \mathrm{T}$ cells $(0.332 \%$ in HT vs $44 \%$ in PTC), which is in conflict with what one would expect as multiple other diseases are associated with increased Treg. However, the data are supported by a study by Marazuela et al. who isolated mononuclear cells from 14 patients with autoimmune thyroid and determined $\mathrm{CD}^{+}{ }^{+} \mathrm{FOXP}^{+}{ }^{+}$cells to be $<0.5 \%$ (Marazuela et al. 2006).

The study by Imam et al. comprises the challenge to rule out a potential contamination by effector T cells $\left(\mathrm{CD} 25^{+}\right)$as there is no specific maker for DN Tregs. DN Tregs have to be distinguished from other $\mathrm{CD} 4^{-} / \mathrm{CD}^{-}$populations such as mucosa-associated invariant T (MAIT) cells and, importantly, invariant NKT (iNKT) cells that are frequently $\mathrm{CD}^{-} / \mathrm{CD}^{-}$(Treiner \& Lantz 2006). Imam et al. present experiments show that the DN cells after stimulation with ionomycin/phorbol-12-myristate-13-acetate (PMA) produce high levels of IFN $\gamma$ that has been shown to act pro tumorigenic. Thus, these DN cells appear to behave like effector cells. Furthermore, the observation that DN cells produce IL17 under stimulation requires further discussion. It is thought that IL17 is a key cytokine also produced predominantly by effector $\mathrm{T}$ cells $\left(\mathrm{CD} 4^{+}\right)$, whereas $\mathrm{CD} 4^{-}$ cells only have limited potential to express IL17.

Th17 cells are thought to be the predominant source of IL17 in HT. However, others have shown alternate mechanism to induce HT by using a NOD-H2h4 mice model, which are deficient for IL17. In this model, the depletion of Tregs leads to the development of autoimmune thyroiditis. The authors argued that an increase in Th1 cell as a result of a Treg depletion can induce thyroiditis (Horie et al. 2011). Thus these alternate mechanisms of HT genesis might explain the observations made by Imam et al. and might set the stage for the expansion of a DN cell population.

In addition, Fountoulakis et al. (2007) have elucidated the role of iodine in the progression of thyroid autoimmunity. This group described an inverse relationship between serum IL17 and HT progression that might be explained by a more cytotoxic responses of Th1 compared with Th17. The group developed a mouse model and

Published by Bioscientifica Ltd. 
showed that moderate iodine intake promotes Th17 while excessive iodine supplementation induce Th1 cells that in turn caused autoimmunity and thyroid cell apoptosis. Therefore, iodine intake might potentially effect and regulate the micro milieau. Thus, $\mathrm{CD}^{+}$cell polarization likely plays an important role not only in HT but also in PTC and there is a plasticity between protective Th1 or Th17 and evasive Th2 or Treg response. Indeed, the presence of DN T cells might be a novel regulatory factor and not due to effecter cell contamination. This notion is also supported by a Crispin et al. (2008), who described IL17-secreting DNT cells derived from a CD8 ${ }^{+}$precursor in lupus patients.

Overall, the study by Imam et al. provides an interesting new view on the role of tumor-associated DN $\mathrm{T}$ cells with potentially immunomodulatory activity in PTC. However, it becomes clear that extensive further research is required to fully understand the whole picture. It is evident that the $\mathrm{T}$ cell infiltration is very heterogenous. This is not only true between different thyroid disease (i.e. PTC, TNG, and HT), but also within each defined entity there appears to be a rather heterogenous and maybe observer-dependent admixture and expression of the various $\mathrm{T}$ cell fractions. This might be due to technical limitations and also environmental factors.

As the final decision on the role of immune system in differentiated thyroid cancer will take some time, it is important to further characterize the function of these DN T cells found in PTC. Therefore these cells should be sorted and tested for immune-suppressive functions in $\mathrm{T}$ cell suppression assays. Future studies will also be necessary to evaluate how the immune cell infiltration influences the clinical outcome of PTC. For that purpose, it would be important to identify the presence of $\mathrm{DN}$ $\mathrm{T}$ cells in patients with aggressive PTC and those with more indolent stage I disease.

\section{Declaration of interest}

The authors declare that there is no conflict of interest that could be perceived as prejudicing the impartiality of the research reported.

\section{Funding}

This research did not receive any specific grant from any funding agency in the public, commercial or not-for-profit sector.

\section{References}

Akdis CA \& Akdis M 2009 Mechanisms and treatment of allergic disease in the big picture of regulatory T cells. Journal of Allergy and Clinical
Immunology 123 735-746 (quiz 747-748). (doi:10.1016/j.jaci. 2009.02.030)

Balkwill F \& Mantovani A 2001 Inflammation and cancer: back to Virchow? Lancet 357 539-545. (doi:10.1016/S0140-6736(00)04046-0)

Bluestone JA, Liu W, Yabu JM, Laszik ZG, Putnam A, Belingheri M, Gross DM, Townsend RM \& Vincenti F 2008 The effect of costimulatory and interleukin 2 receptor blockade on regulatory T cells in renal transplantation. American Journal of Transplantation 8 2086-2096. (doi:10.1111/j.1600-6143.2008.02377.x)

Caturegli P, De Remigis A, Chuang K, Dembele M, Iwama A \& Iwama S 2013 Hashimoto's thyroiditis: celebrating the centennial through the lens of the Johns Hopkins hospital surgical pathology records. Thyroid $\mathbf{2 3}$ 142-150. (doi:10.1089/thy.2012.0554)

Chen W, Jin W, Hardegen N, Lei KJ, Li L, Marinos N, McGrady G \& Wahl SM 2003 Conversion of peripheral CD4 + CD25 - naive T cells to $\mathrm{CD} 4+\mathrm{CD} 25+$ regulatory $\mathrm{T}$ cells by TGF- $\beta$ induction of transcription factor Foxp3. Journal of Experimental Medicine 198 1875-1886. (doi:10.1084/jem.20030152)

Coussens LM \& Werb Z 2002 Inflammation and cancer. Nature 420 860-867. (doi:10.1038/nature01322)

Coutinho A, Caramalho I, Seixas E \& Demengeot J 2005 Thymic commitment of regulatory $\mathrm{T}$ cells is a pathway of TCR-dependent selection that isolates repertoires undergoing positive or negative selection. Current Topics in Microbiology and Immunology 293 43-71. (doi:10.1007/3-540-27702-1)

Crispin JC, Oukka M, Bayliss G, Cohen RA, Van Beek CA, Stillman IE, Kyttaris VC, Juang YT \& Tsokos GC 2008 Expanded double negative $\mathrm{T}$ cells in patients with systemic lupus erythematosus produce IL-17 and infiltrate the kidneys. Journal of Immunology 181 8761-8766. (doi:10.4049/jimmunol.181.12.8761)

Di Pasquale M, Rothstein JL \& Palazzo JP 2001 Pathologic features of Hashimoto's-associated papillary thyroid carcinomas. Human Pathology 32 24-30. (doi:10.1053/hupa.2001.21138)

Dittel BN 2008 CD4 T cells: balancing the coming and going of autoimmune-mediated inflammation in the CNS. Brain, Behavior, and Immunity 22 421-430. (doi:10.1016/j.bbi.2007.11.010)

Eisenberg BL \& Hensley SD 1989 Thyroid cancer with coexistent Hashimoto's thyroiditis. Clinical assessment and management. Archives of Surgery 124 1045-1047. (doi:10.1001/archsurg.1989. 01410090055012)

Fountoulakis S, Philippou G \& Tsatsoulis A 2007 The role of iodine in the evolution of thyroid disease in Greece: from endemic goiter to thyroid autoimmunity. Hormones 6 25-35.

French JD, Weber ZJ, Fretwell DL, Said S, Klopper JP \& Haugen BR 2010 Tumor-associated lymphocytes and increased FoxP3 + regulatory T cell frequency correlate with more aggressive papillary thyroid cancer. Journal of Clinical Endocrinology and Metabolism 95 2325-2333. (doi:10.1210/jc.2009-2564)

Gogali F, Paterakis G, Rassidakis GZ, Kaltsas G, Liakou CI, Gousis P, Neonakis E, Manoussakis MN \& Liapi C 2012 Phenotypical analysis of lymphocytes with suppressive and regulatory properties (Tregs) and NK cells in the papillary carcinoma of thyroid. Journal of Clinical Endocrinology and Metabolism 97 1474-1482. (doi:10.1210/ jc.2011-1838)

Grivennikov SI \& Karin M 2010 Inflammation and oncogenesis: a vicious connection. Current Opinion in Genetics \& Development 20 65-71. (doi:10.1016/j.gde.2009.11.004)

Guarino V, Castellone MD, Avilla E \& Melillo RM 2010 Thyroid cancer and inflammation. Molecular and Cellular Endocrinology 321 94-102. (doi:10.1016/j.mce.2009.10.003)

Hillhouse EE \& Lesage S 2013 A comprehensive review of the phenotype and function of antigen-specific immunoregulatory double negative T cells. Journal of Autoimmunity 40 58-65. (doi:10.1016/j.jaut.2012. 07.010)

Horie I, Abiru N, Sakamoto H, Iwakura Y \& Nagayama Y 2011 Induction of autoimmune thyroiditis by depletion of $\mathrm{CD} 4+\mathrm{CD} 25+$ regulatory

Published by Bioscientifica Ltd. 
$\mathrm{T}$ cells in thyroiditis-resistant IL-17, but not interferon-gamma receptor, knockout nonobese diabetic-H2h4 mice. Endocrinology 152 4448-4454. (doi:10.1210/en.2011-1356)

Imam S, Paparodis R, Sharma D \& Jaume JC 2014 Lymphocytic profiling in thyroid cancer provides clues for failure of tumor immunity. Endocrine-Related Cancer 21 505-516. (doi:10.1530/ERC-13-0436)

Jankovic B, Le KT \& Hershman JM 2013 Clinical Review: Hashimoto's thyroiditis and papillary thyroid carcinoma: is there a correlation? Journal of Clinical Endocrinology and Metabolism 98 474-482. (doi:10.1210/jc.2012-2978)

Juvet SC \& Zhang L 2012 Double negative regulatory T cells in transplantation and autoimmunity: recent progress and future directions. Journal of Molecular Cell Biology 4 48-58. (doi:10.1093/ jmcb/mjr043)

Kashima K, Yokoyama S, Noguchi S, Murakami N, Yamashita H, Watanabe S, Uchino S, Toda M, Sasaki A, Daa T et al. 1998 Chronic thyroiditis as a favorable prognostic factor in papillary thyroid carcinoma. Thyroid 8 197-202. (doi:10.1089/thy.1998.8.197)

Kebebew E, Treseler PA, Ituarte PH \& Clark OH 2001 Coexisting chronic lymphocytic thyroiditis and papillary thyroid cancer revisited. World Journal of Surgery 25 632-637. (doi:10.1007/s002680020165)

Loh KC, Greenspan FS, Dong F, Miller TR \& Yeo PP 1999 Influence of lymphocytic thyroiditis on the prognostic outcome of patients with papillary thyroid carcinoma. Journal of Clinical Endocrinology and Metabolism 84 458-463. (doi:10.1210/jcem.84.2.5443)

Ma Y, He KM, Garcia B, Min W, Jevnikar A \& Zhang ZX 2008 Adoptive transfer of double negative $T$ regulatory cells induces B-cell death in vivo and alters rejection pattern of rat-to-mouse heart transplantation. Xenotransplantation 15 56-63. (doi:10.1111/j.1399-3089.2008.00444.x)

Marazuela M, Garcia-Lopez MA, Figueroa-Vega N, de la Fuente H, Alvarado-Sanchez B, Monsivais-Urenda A, Sanchez-Madrid F \& Gonzalez-Amaro R 2006 Regulatory T cells in human autoimmune thyroid disease. Journal of Clinical Endocrinology and Metabolism 91 3639-3646. (doi:10.1210/jc.2005-2337)

Mechler C, Bounacer A, Suarez H, Saint Frison M, Magois C, Aillet G \& Gaulier A 2001 Papillary thyroid carcinoma: 6 cases from 2 families with associated lymphocytic thyroiditis harbouring RET/PTC rearrangements. British Journal of Cancer 85 1831-1837. (doi:10.1054/ bjoc.2001.2187)

Muranski P \& Restifo NP 2013 Essentials of Th17 cell commitment and plasticity. Blood 121 2402-2414. (doi:10.1182/blood-2012-09-378653)

Nishikawa H \& Sakaguchi S 2010 Regulatory T cells in tumor immunity. International Journal of Cancer 127 759-767.

Ott RA, McCall AR, McHenry C, Jarosz H, Armin A, Lawrence AM \& Paloyan E 1987 The incidence of thyroid carcinoma in Hashimoto's thyroiditis. American Surgeon 53 442-445.

Peterson RA 2012 Regulatory T-cells: diverse phenotypes integral to immune homeostasis and suppression. Toxicologic Pathology $\mathbf{4 0}$ 186-204. (doi:10.1177/0192623311430693)

Pisanu A, Piu S, Cois A \& Uccheddu A 2003 Coexisting Hashimoto's thyroiditis with differentiated thyroid cancer and benign thyroid diseases: indications for thyroidectomy. Chirurgia Italiana 55 365-372.

Sakaguchi S, Miyara M, Costantino CM \& Hafler DA 2010 FOXP3+ regulatory $\mathrm{T}$ cells in the human immune system. Nature Reviews. Immunology 10 490-500. (doi:10.1038/nri2785)

Segal K, Ben-Bassat M, Avraham A, Har-El G \& Sidi J 1985 Hashimoto's thyroiditis and carcinoma of the thyroid gland. International Surgery $\mathbf{7 0}$ 205-209.

Shevach EM 2009 Mechanisms of foxp3 + T regulatory cell-mediated suppression. Immunity 30 636-645. (doi:10.1016/j.immuni.2009. 04.010)

Simpson RJ, Cosgrove C, Ingram LA, Florida-James GD, Whyte GP, Pircher H \& Guy K 2008 Senescent T-lymphocytes are mobilised into the peripheral blood compartment in young and older humans after exhaustive exercise. Brain, Behavior, and Immunity 22 544-551. (doi:10.1016/j.bbi.2007.11.002)

Strober S, Cheng L, Zeng D, Palathumpat R, Dejbakhsh-Jones S, Huie P \& Sibley R 1996 Double negative $(C D 4-C D 8-\alpha \beta+)$ T cells which promote tolerance induction and regulate autoimmunity. Immunological Reviews 149 217-230. (doi:10.1111/j.1600-065X. 1996.tb00906.x)

Treiner E \& Lantz O 2006 CD1d- and MR1-restricted invariant T cells: of mice and men. Current Opinion in Immunology 18 519-526. (doi:10.1016/j.coi.2006.07.001)

Received in final form 8 May 2014

Accepted 9 May 2014

Made available online as an Accepted Preprint

13 May 2014 http://erc.endocrinology-journals.org

DOI: 10.1530/ERC-14-0229
(C) 2014 Society for Endocrinology Printed in Great Britain
Published by Bioscientifica Ltd. 